\title{
Exploring Relationships between Ethical Consumption, Lifestyle Choices, and Social Responsibility
}

\author{
Carissa J. Morgan ${ }^{1}$, Candace C. Croney ${ }^{2}$, Nicole J. Olynk Widmar ${ }^{{ }^{*}}$ \\ ${ }^{1}$ Department of Agricultural Economics, Purdue University, West Lafayette, IN, USA \\ ${ }^{2}$ Purdue University College of Veterinary Medicine, West Lafayette, IN, USA \\ Email:cmccay@purdue.edu,ccroney@purdue.edu, "nwidmar@purdue.edu
}

Received 26 March 2016; accepted 10 May 2016; published 13 May 2016

Copyright (C) 2016 by authors and Scientific Research Publishing Inc.

This work is licensed under the Creative Commons Attribution International License (CC BY). http://creativecommons.org/licenses/by/4.0/

(c) (i) Open Access

\begin{abstract}
Despite increased discussion about "ethical consumerism", insufficient attention has been given to consumers' attitudes in regard to socio-ethical issues and how well they may align with their corporate social responsibility (CSR) expectations. An online survey of 1201 US consumers was conducted to determine how demographics and lifestyle choices might reflect and inform purchasing decisions. Women, younger respondents and more educated respondents were more likely to value and support environmental protection aspects of social responsibility in their consumption behaviors. Women and younger respondents were also more sensitive to animal welfare concerns, as were vegetarians and vegans, who also strongly supported environmental protection through consumption. Those who traveled, volunteered or engaged in charitable giving also reported more highly valuing the environmental, animal welfare, corporate responsibility and philanthropic dimensions of social responsibility. All demographics reported avoiding companies that used advertisements that were deceptive or depicted minorities negatively. Collectively, this analysis suggests that a wide array of ethical concerns are considered by many US consumers in their current purchasing behaviors and that the values underlying their actions may indeed hold implications for consumer perceptions of and support for corporations and their CSR initiatives.
\end{abstract}

\section{Keywords}

Consumer Preferences, Personal Social Responsibility, Ethical Consumerism, Corporate Social Responsibility, Lifestyle

\footnotetext{
${ }^{*}$ Corresponding author.
}

How to cite this paper: Morgan, C. J., Croney, C. C., \& Widmar, N. J. O. (2016). Exploring Relationships between Ethical Consumption, Lifestyle Choices, and Social Responsibility. Advances in Applied Sociology, 6, 199-216. 


\section{Introduction}

There is increasing evidence that in many developed nations, a growing segment of consumers is interested in demonstrating social consciousness via their purchasing behavior. Such ethical consumers are interested in purchasing products and services that align with their values relative to social and environmental responsibility (Roberts, 1995; Shaw et al., 2005). These individuals may be concerned about social issues, including environmental protection, animal welfare and issues pertaining to human rights, such as fair labor. Not surprisingly, socially responsible consumers attempt to avoid purchasing products that they perceive may disadvantage or infringe on the health and well-being of animals, the environment, or vulnerable people (Elkington \& Hailes, 1989; Shaw et al., 2005).

Since individuals attempting to make ethically responsible purchases are likely to rely upon the credibility of a company's brands and labels, their perceptions of corporate social responsibility (CSR) must be considered. CSR encompasses the notion that businesses have social and ethical obligations to diverse groups beyond those to whom they are immediately accountable, such as their investors, members of their respective supply chains and employees, and that their responsibilities extend even to the local and global communities who may be impacted by their operations (Maloni \& Brown, 2006). While studies of CSR perceptions are abundant, the underlying values, interests and lifestyle choices associated with consumer social responsibility and their relationship to CSR perceptions have received comparatively little attention. Few studies have focused on the lifestyle choices associated with consumer social responsibility (Roberts, 1995), which makes it difficult to know to what extent ethical consumer behaviors may be related to perceptions of CSR. Values guide people's beliefs and assessment of appropriate actions and policies, and they provide a basis for motivating people to act accordingly (Schwartz, 1992). Therefore insight into to consumers' values and behaviors is germane to understanding their CSR perceptions.

As noted by Golob et al. (2008), not only are peoples' expectations of CSR changing, their values are evolving and are increasingly expressed via their purchasing behaviors. Basil and Weber (2006) have suggested that CSR expectations are closely tied to consumers' value orientations. Lack of knowledge about consumers' values and beliefs (and how these drive people's perceptions of their own and others' ethical behavior) is problematic since such beliefs very likely inform their decision-making about corporations and brands (Crane, 2005; Brunk, 2010). Further to this point, Auger et al. (2007) observes that lack of clarity relative to understanding what social responsibility means to a given society can result in practices and policies that are misaligned with public expectations, and are consequently, ineffective. Although the usefulness of demographic profiling of ethical consumers has been debated, several studies have noted that this type of consumer tends to be well educated, urban, and of sufficiently high income to afford the premiums (Wehrmeyer, 1992) that are typically charged for positive social and environmental welfare attributes.

This study sought to collect information about consumer lifestyle choices and demographics that might reflect and inform personal socio-ethical behaviors and to examine the implications for perceived CSR. Because ethical concerns may encompass several dimensions, this study incorporated concepts of socially responsible consumer behaviors as described by Roberts (1995). Socially responsible consumers were defined as those who consider the environmental impacts of their purchasing behavior and attempt to buy products or services that either positively influence the environment (or do the least harm) or those who use their purchasing power as a means of expressing their socio-ethical concerns (Roberts, 1995). Expanding on Roberts' (1995) concepts, consumer behaviors and attitudes on topics ranging from dietary choices to environmental and social concerns were explored.

\section{Materials and Methods}

The data used in this analysis were obtained from an online US national scale survey conducted in April 2015 focused on personal social responsibility and perceptions of CSR practices. Previous studies have reported that people's perceptions are shaped by their frames of reference (Te Velde et al., 2002; McKendree et al., 2014). The intent of the research was to analyze possible relationships between personal practices and perceptions of corporate practices. The underlying assumption is that people act from their beliefs and personal values. Thus, the survey asked questions about consumer households' food consumption habits, personal social practices (travel, volunteerism and charitable giving), and personal social responsibility behaviors.

The survey was conducted online to facilitate obtaining a national sample and allow reasonable randomization 
of questions and possible responses. The sample was targeted to be representative of the US population in terms of gender, age, income, and geographic region of residence. The sample of consumers was obtained through a large opt-in panel, managed by Lightspeed GMI. Qualtrics was used to host the survey online, pretest the survey, and complete basic data organization. The total sample analyzed included 1201 people. Table 1 shows demographic information for all survey participants.

Table 1. Sample demographics $(n=1201)$.

\begin{tabular}{|c|c|}
\hline Variable description & Survey \\
\hline & Frequency (\%) \\
\hline Female & 51 \\
\hline \multicolumn{2}{|l|}{ Age } \\
\hline 18 to 24 years & 13 \\
\hline 25 to 44 years & 35 \\
\hline 45 to 64 years & 35 \\
\hline 65 years and over & 17 \\
\hline \multicolumn{2}{|l|}{ Household Income } \\
\hline Less than $\$ 25,000$ & 23 \\
\hline$\$ 25,000-\$ 34,999$ & 11 \\
\hline$\$ 35,000$ - \$49,999 & 14 \\
\hline$\$ 50,000$ - \$74,999 & 18 \\
\hline$\$ 75,000$ - \$99,999 & 12 \\
\hline$\$ 100,000$ - \$149,999 & 13 \\
\hline$\$ 150,000$ or more & 9 \\
\hline \multicolumn{2}{|l|}{ Region } \\
\hline Northeast & 18 \\
\hline South & 38 \\
\hline Midwest & 22 \\
\hline West & 22 \\
\hline \multicolumn{2}{|l|}{ Education } \\
\hline Did not graduate from high school & 2 \\
\hline Graduated from high school, did not attend college & 19 \\
\hline Attended college, no degree earned & 21 \\
\hline $\begin{array}{l}\text { Attended college, associate or trade } \\
\text { degree earned }\end{array}$ & 13 \\
\hline Attended college, bachelor's (B.S. or B.A.) degree earned & 28 \\
\hline $\begin{array}{l}\text { Attended college, advanced } \\
\text { (M.S., Ph.D., Law School) degree earned }\end{array}$ & 16 \\
\hline Other & 1 \\
\hline \multicolumn{2}{|l|}{ Vegetarian (\% of responses) } \\
\hline I or a member of my household is & 14 \\
\hline A close friend or family member is & 16 \\
\hline No, neither I nor anyone I know is & 70 \\
\hline \multicolumn{2}{|l|}{ Vegan (\% of responses) } \\
\hline I or a member of my household is & 9 \\
\hline A close friend or family member is & 5 \\
\hline No, neither I nor anyone I know is & 86 \\
\hline
\end{tabular}


This study sought to identify how respondents' personal ethics might relate to their perceptions of CSR, therefore consumer behaviors that are likely to be ethically driven were of particular interest. This study heavily based its inquiry into respondents' ethical behaviors on the work of Roberts (1995), which profiled socially responsible behaviors in consumers. The full list of 15 statements used in this study are listed in Table 2. Statements 1 - 9 and 11 were taken directly from Roberts (1995). Statement 10 was modified from Roberts (1995), and statements 12 - 15 were developed for the purposes of this specific analysis. Survey participants were asked to rate each of their own personal practices as either "never true", "rarely true", "sometimes true", or "always true". For analysis and presentation of results, participant responses were grouped into two categories, "never or rarely true" and "always or sometimes true".

A series of questions pertaining to social practices, including experience in traveling, volunteering, and giving to charities were posed to survey participants. Consumers were asked if they had traveled in the past five years and the reason for the majority of their travels. A similar format was used to examine participants' volunteer experience and charitable giving. Survey participants were asked if and why they regularly donated to charities, and what types of organizations they support.

Interrelationships between variables, including demographics, travel experience, volunteering, giving to charities, and responses to the above-stated ethical statements were of interest. Cross-tabulations were created to look at interrelationships between variables.

\section{Results and Discussion}

Responses to Roberts (1995) statements and those developed for this analysis are shown in Table 2. The majority

Table 2. Survey summary responses to ethical statements (values given in \% of respondents).

\begin{tabular}{|c|c|c|c|}
\hline $\begin{array}{l}\text { Ethical } \\
\text { statement } \\
\text { number }\end{array}$ & & $\begin{array}{c}\text { Never or } \\
\text { rarely } \\
(\%)\end{array}$ & $\begin{array}{c}\text { Sometimes or } \\
\text { always } \\
(\%)\end{array}$ \\
\hline 1 & $\begin{array}{l}\text { When I have the choice between two equal products, I always purchase } \\
\text { the one that is less harmful to the environment. }\end{array}$ & 37 & 63 \\
\hline 2 & I try to buy products that can be recycled. & 31 & 69 \\
\hline 3 & $\begin{array}{l}\text { When there is a choice, I always choose the product which contributes to } \\
\text { the least amount of pollution. }\end{array}$ & 42 & 58 \\
\hline 4 & Whenever possible, I buy products packaged in recyclable containers. & 39 & 61 \\
\hline 5 & $\begin{array}{l}\text { I have convinced members of my family or friends not to buy some } \\
\text { products which are harmful to the environment. }\end{array}$ & 63 & 37 \\
\hline 6 & $\begin{array}{l}\text { I make a conscious effort to limit my use of products that are made of or } \\
\text { use scarce resources. }\end{array}$ & 47 & 53 \\
\hline 7 & $\begin{array}{l}\text { I do not buy products with advertising that depicts minority groups in a } \\
\text { negative way. }\end{array}$ & 44 & 56 \\
\hline 8 & I do not buy a product that uses deceptive advertising. & 31 & 69 \\
\hline 9 & I do not buy products from companies involved in a labor dispute. & 63 & 37 \\
\hline 10 & $\begin{array}{l}\text { I do not buy meat or milk because of the conditions under which the } \\
\text { workers who produce them live and work. }\end{array}$ & 70 & 30 \\
\hline 11 & I try to purchase from companies who make donations to charity. & 49 & 51 \\
\hline 12 & $\begin{array}{l}\text { I actively look to purchase milk products which promote } \\
\text { welfare-friendly conditions for the livestock animals that produce them. }\end{array}$ & 53 & 47 \\
\hline 13 & $\begin{array}{l}\text { I do not purchase eggs produced from hens housed in contentious } \\
\text { conditions. }\end{array}$ & 58 & 42 \\
\hline 14 & $\begin{array}{l}\text { I do not buy dairy products produced on dairy farms that use hormone } \\
\text { supplements. }\end{array}$ & 51 & 49 \\
\hline 15 & $\begin{array}{l}\text { I do not buy meat products from farms that do not allow the cattle access } \\
\text { to pasture. }\end{array}$ & 59 & 41 \\
\hline
\end{tabular}


of consumers answered "always or sometimes true" regarding statements 1, 2, 3, 4, 6, 7, 8, and 11. Sixty-nine percent of respondents indicated high agreement (69\%) with statements 2 and 8 . In contrast, the majority of consumers indicated "never or rarely true" to consumption statements regarding animal welfare practices (statements 10, 12 - 15).

\subsection{Demographic Information}

\subsubsection{Gender}

The sample in this study was $51 \%$ female (Table 1); a complete listing of social responsibility statements by gender (cross-tabulations) is presented in Table 3. Consistent with previous studies (Vanhonacker et al., 2007; McKendree et al., 2014), women appeared to have greater concern for some aspects of animal welfare than men, responding "always or sometimes true" more often than men to statement 13 and 15 . In addition, more women selected "always or sometimes true" to statement 14. It is impossible to determine whether respondents viewed hormone supplementation of dairy cows as an animal welfare or food safety issue, and it is likely that at least some may have had concerns about both of these aspects. In contrast, no differences were seen on statement 12.

The women's responses also suggested that they acted to protect the environment more often, responding "always or sometimes true" in response to statements 1,2 and 6 . No significant gender differences were observed for statement 5. Collectively, these results suggest that for women, animal welfare, environmental protection, and perhaps also food safety were high priorities. This finding is consistent with those of Wandel and Bugge (1997) wherein women tended to more highly prioritize environmental aspects in regard to their assessments and purchasing of food quality than men did. On statements related to social consciousness (fair labor), there were no differences in responses to statements 9 and 10. Interestingly, a large majority of both male and female respondents responded "never or rarely true" to statement 10. This suggests either lack of concern for worker well-being or lack of knowledge of potentially problematic worker conditions that might trigger concerns. However, a limitation of the current study is that it is impossible to determine which, if either, explanation is correct.

In regard to corporate ethics and philanthropy, there were significant differences between men and women in response to statements 7 and 8 . While a greater percentage of women responded "always or sometimes true" to both these statements, a substantial proportion of men selected "always or mostly true" to statement 8 , suggesting that both men and women highly value truth in advertising.

\subsubsection{Age}

Differences were observed in responses to almost every category of the ethical inquiry across age categories (Table 3). Substantial differences were observed between the responses of older (65+) and younger (25 - 44) respondents in response to statements 5, 10 and 13. For each of these statements, the tendency to respond with "always or sometimes true" decreased as age increased. This suggests that younger respondents were more socially conscious and inclined toward activism via convincing others not to act in ways they deemed harmful (Fox, 2012), and they were more sensitive to certain aspects of animal welfare (Verhue \& Verzeijden, 2003; Vanhonacker et al., 2007; McKendree et al., 2014). Only a small difference was found between 18 - 24 year olds and 45 - 64 year olds on statement 2 , where a higher percentage of the older category selected "always or sometimes true".

\subsection{Education}

Fifty-seven percent of people participating in this study had earned a college degree; $28 \%$ held a Bachelor's degree (Table 1). There were significant differences associated with education level across most categories of the ethical inquiry, particularly those relating to environmental concern statements 1 - 6 (Table 3). Respondents who had earned a degree beyond high school selected "always or sometimes true" for all statements more than those who had not. Nowhere was the difference across education levels more obvious than in response to statement 6; those having an Associate's degree or higher more often responded "always or sometimes true" to this statement, potentially suggesting that advanced degree holders were either more knowledgeable about scarce resources and/or that they were more inclined to value environmental responsibility in consumption. Although a causal relationship cannot be deduced and reasons for the differences are purely speculative, an association between education and environmental concern is consistent with studies reporting a positive relationship between 
Table 3. Relationships between participants’ demographics and responding "always or sometimes true” to social responsibility inquiry (\% of respondents) ${ }^{1}$.

\begin{tabular}{|c|c|c|c|c|c|c|c|c|c|c|c|c|}
\hline \multirow[b]{2}{*}{ Е } & \multicolumn{2}{|c|}{ Gender $^{2}$} & \multicolumn{4}{|c|}{ Age (in years) ${ }^{3}$} & \multicolumn{6}{|c|}{ Education $^{4}$} \\
\hline & $\underbrace{\sim}_{\frac{*}{0}}$ & 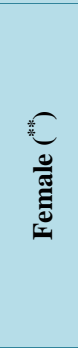 & 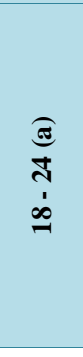 & \begin{tabular}{l}
2 \\
\multirow{2}{*}{} \\
1 \\
กุ
\end{tabular} & 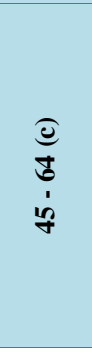 & $\begin{array}{l}\text { 己ै } \\
+ \\
\text { 苟 }\end{array}$ & 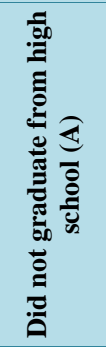 & 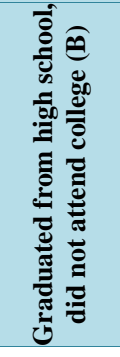 & 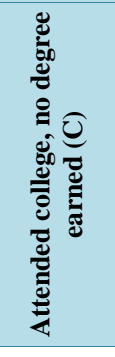 & 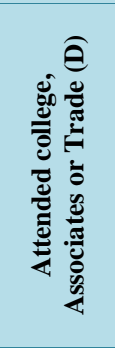 & 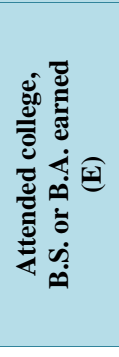 & 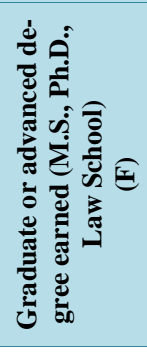 \\
\hline $\begin{array}{l}\text { When I have a choice } \\
\text { between two equal products, } \\
\text { I always purchase the one } \\
\text { that is less harmful to } \\
\text { the environment. }\end{array}$ & $60.1^{* *}$ & $65.9^{*}$ & $58.0^{\mathrm{b}}$ & $67.6^{\mathrm{a}, \mathrm{d}}$ & 62.7 & $58.5^{\mathrm{b}}$ & 58.3 & $55.5^{\mathrm{E}, \mathrm{F}}$ & $55.2^{\mathrm{E}, \mathrm{F}}$ & 64.2 & $70.5^{\mathrm{B}, \mathrm{C}}$ & $68.7^{\mathrm{B}, \mathrm{C}}$ \\
\hline $\begin{array}{l}\text { I try to buy products } \\
\text { that can be recycled. }\end{array}$ & $65.7^{* *}$ & $71.3^{*}$ & $63.7^{c}$ & 67.4 & $72.5^{\mathrm{a}}$ & 66.3 & 62.5 & $63.6^{\mathrm{E}, \mathrm{F}}$ & $62.8^{\mathrm{E}, \mathrm{F}}$ & 67.9 & $72.9^{\mathrm{B}, \mathrm{C}}$ & $75.9^{\mathrm{B}, \mathrm{C}}$ \\
\hline $\begin{array}{l}\text { When there is a choice, I } \\
\text { always choose the product } \\
\text { which contributes to the } \\
\text { least amount of pollution. }\end{array}$ & $55.2^{* *}$ & $61.3^{*}$ & 59.2 & $62.4^{\mathrm{d}}$ & 56.9 & $51.7^{\mathrm{b}}$ & 54.2 & $50.5^{\mathrm{D}, \mathrm{E}, \mathrm{F}}$ & $52.4^{\mathrm{D}, \mathrm{E}, \mathrm{F}}$ & $61.6^{\mathrm{B}}$ & $64.6^{\mathrm{B}, \mathrm{C}}$ & $62.6^{\mathrm{B}, \mathrm{C}}$ \\
\hline $\begin{array}{l}\text { Whenever possible, I buy } \\
\text { products packaged in } \\
\text { reusable containers. }\end{array}$ & $58.2^{* *}$ & $64.1^{*}$ & 65.0 & $64.0^{\mathrm{d}}$ & 59.6 & $55.6^{\mathrm{b}}$ & 62.5 & 60.0 & $53.2^{\mathrm{D}, \mathrm{E}, \mathrm{F}}$ & $63.5^{\mathrm{C}}$ & $65.2^{\mathrm{C}}$ & $65.1^{\mathrm{C}}$ \\
\hline $\begin{array}{l}\text { I have convinced members } \\
\text { of my family or friends } \\
\text { not to buy some } \\
\text { products which are } \\
\text { harmful to the environment. }\end{array}$ & 37.4 & 37.4 & $45.9^{\mathrm{c}, \mathrm{d}}$ & $46.4^{\mathrm{c}, \mathrm{d}}$ & $32.8^{\mathrm{a}, \mathrm{b}, \mathrm{d}}$ & $21.5^{\mathrm{a}, \mathrm{b}, \mathrm{c}}$ & $20.8^{\mathrm{D}, \mathrm{E}}$ & $30.5^{\mathrm{D}, \mathrm{E}, \mathrm{F}}$ & $32.8^{\mathrm{E}}$ & $42.1^{\mathrm{A}, \mathrm{B}}$ & $42.8^{\mathrm{A}, \mathrm{B}, \mathrm{C}}$ & $40.0^{\mathrm{B}}$ \\
\hline $\begin{array}{l}\text { I make a conscious effort } \\
\text { to limit my use of } \\
\text { products that } \\
\text { are made of or use } \\
\text { scarce resources. }\end{array}$ & $49.7^{* *}$ & $56.9^{*}$ & 55.4 & $57.1^{d}$ & 52.4 & $45.9^{\mathrm{b}}$ & $33.3^{\mathrm{D,E}, \mathrm{F}}$ & $45.9^{\mathrm{D}, \mathrm{E}, \mathrm{F}}$ & $48.4^{\mathrm{D}, \mathrm{E}, \mathrm{F}}$ & $61.0^{\mathrm{A}, \mathrm{B}, \mathrm{C}}$ & $56.6^{\mathrm{A}, \mathrm{B}, \mathrm{C}}$ & $60.0^{\mathrm{A}, \mathrm{B}, \mathrm{C}}$ \\
\hline $\begin{array}{l}\text { I do not buy products } \\
\text { with advertising that } \\
\text { depicts minority groups } \\
\text { in a negative way }\end{array}$ & $50.4_{* *}$ & $60.5 *$ & 58.0 & 58.1 & 53.1 & 53.7 & 50.0 & $48.2_{\mathrm{D}, \mathrm{E}}$ & 55.2 & $61.6_{\mathrm{B}}$ & $57.5_{\mathrm{B}}$ & 56.9 \\
\hline $\begin{array}{l}\text { I do not buy a product that } \\
\text { uses deceptive advertising. }\end{array}$ & $66.0^{* *}$ & $71.5^{*}$ & $63.1^{\mathrm{d}}$ & $65.5^{\mathrm{d}}$ & 71.1 & $75.6^{\mathrm{a}, \mathrm{b}}$ & $50.0^{\mathrm{D}, \mathrm{E}}$ & $62.7^{\mathrm{E}}$ & 69.2 & $71.7^{\mathrm{A}}$ & $71.7^{\mathrm{A}, \mathrm{B}}$ & 69.2 \\
\hline $\begin{array}{l}\text { I do not buy products } \\
\text { from companies involved } \\
\text { in a labor dispute. }\end{array}$ & 36.0 & 37.5 & 38.9 & $40.0^{\mathrm{d}}$ & 35.4 & $31.2^{b}$ & 35.0 & 34.1 & 33.2 & 40.9 & 39.5 & 37.9 \\
\hline $\begin{array}{l}\text { I do not buy meat or } \\
\text { milk because of the } \\
\text { conditions under which } \\
\text { the workers who produce } \\
\text { them live and work. }\end{array}$ & 29.3 & 30.7 & $41.4^{\mathrm{c}, \mathrm{d}}$ & $36.2^{\mathrm{c}, \mathrm{d}}$ & $23.7^{\mathrm{a}, \mathrm{b}}$ & $21.0^{\mathrm{a}, \mathrm{b}}$ & 20.8 & 28.6 & $28.8^{\mathrm{E}}$ & $27.0^{\mathrm{E}}$ & $36.6^{\mathrm{C}, \mathrm{D}, \mathrm{F}}$ & $25.1^{\mathrm{E}}$ \\
\hline $\begin{array}{l}\text { I try to purchase from } \\
\text { companies who make } \\
\text { donations to charity. }\end{array}$ & 48.6 & 52.8 & $56.7^{\mathrm{d}}$ & $56.2^{\mathrm{c}, \mathrm{d}}$ & $48.1^{\mathrm{b}}$ & $40.0^{\mathrm{a}, \mathrm{b}}$ & $33.3^{\mathrm{E}, \mathrm{F}}$ & $43.6^{\mathrm{E}, \mathrm{F}}$ & 47.6 & $52.2^{\mathrm{A}, \mathrm{B}}$ & $55.5^{\mathrm{A}, \mathrm{B}}$ & 55.4 \\
\hline
\end{tabular}




\section{Continued}

\begin{tabular}{|c|c|c|c|c|c|c|c|c|c|c|c|c|}
\hline $\begin{array}{l}\text { I actively look to purchase } \\
\text { milk products which } \\
\text { promote welfare-friendly } \\
\text { conditions for the livestock } \\
\text { animals used to } \\
\text { produce them. }\end{array}$ & 44.3 & 49.7 & $51.0^{\mathrm{d}}$ & $53.8^{\mathrm{c}, \mathrm{d}}$ & $43.8^{\mathrm{b}}$ & $37.1^{\mathrm{a}, \mathrm{b}}$ & 50.0 & 47.7 & 42.8 & 51.6 & 49.6 & 42.1 \\
\hline $\begin{array}{l}\text { I do not purchase eggs } \\
\text { produced from hens } \\
\text { housed in contentious } \\
\text { conditions. }\end{array}$ & $37.4^{* *}$ & $46.6^{*}$ & $47.1^{\mathrm{c}, \mathrm{d}}$ & $49.0^{c, d}$ & $38.0^{\mathrm{a}, \mathrm{b}}$ & $31.7^{\mathrm{a}, \mathrm{b}}$ & 37.5 & 43.2 & 38.8 & 39.6 & 45.4 & 41.5 \\
\hline $\begin{array}{l}\text { I do not buy dairy } \\
\text { products produced } \\
\text { on dairy farms that } \\
\text { use hormone supplements. }\end{array}$ & $44.3^{* *}$ & $53.8^{*}$ & 48.4 & $55.2^{\mathrm{c}, \mathrm{d}}$ & $46.4^{\mathrm{b}}$ & $40.5^{\mathrm{b}}$ & 37.5 & 44.5 & 48.0 & 47.8 & 57.5 & 44.6 \\
\hline $\begin{array}{l}\text { I do not buy meat } \\
\text { products from farms } \\
\text { that do not allow } \\
\text { the cattle access } \\
\text { to pasture. }\end{array}$ & $35.5^{* *}$ & $45.7^{*}$ & $43.3^{d}$ & $46.2^{d}$ & $40.4^{\mathrm{d}}$ & $28.3^{\mathrm{a}, \mathrm{b}, \mathrm{c}}$ & 33.3 & 40.5 & $35.2^{\mathrm{E}}$ & 42.8 & $44.5^{C}$ & 39.5 \\
\hline
\end{tabular}

${ }^{1}$ For brevity, this table only includes the "always or sometimes true” percentages for each category. This can be interpreted for the statement "I try to buy products that can be recycled" as $60.1 \%$ of males claim the statement is always or sometimes true of their behavior, while the remaining $39.9 \%$ of males claim the statement is never or rarely true of their behavior. ${ }^{2}$ Significant differences are noted by ${ }^{*},{ }^{* *}$. ${ }^{3}$ Significant differences are noted by a, b, c, d. ${ }^{4}$ Significant differences are noted by A, B, C, D, E, F.

education level and environmental concern (Roberts, 1996; Schwartz \& Miller, 1991; Wandel \& Bugge, 1997).

In regard to the social consciousness and corporate responsibility, statements 7 - 10, a higher percentage of those with an AA degree or higher tended to select "always or sometimes true" than those with less formal education. Statement 10 was an exception to this finding. In contrast with previous studies, there were no significant differences in education level for most of the animal welfare-related statements 12, 13, and 14. For all of these statements, the majority of respondents selected "never or rarely true." Those who had earned a BS degree responded significantly differently, with a higher tendency to select "always or sometimes true" on statement 15 than those who had attended college but not earned a degree.

\section{Vegetarianism and Veganism}

According to a Gallup poll published in 2012, 5\% of Americans considered themselves vegetarian while 2\% claimed to be vegan. In this study, $14 \%$ of respondents indicated that they or a member of their household was vegetarian ( $8 \%$ of respondents were vegetarian and $6 \%$ of the respondents have a vegetarian household member) (Table 1). Four percent of respondents were vegan and 5\% reported a member of their household was vegan.

Respondents who self-identified as vegetarians or had someone in the household who was vegetarian answered significantly differently from those who reported that neither they nor anyone they knew was vegetarian for almost all statements (Table 4). Those who selected "I or a member of my household is vegetarian" answered “always or sometimes true” more often to every statement. Similar to our findings, Fox and Ward (2008) reported a high level and great diversity of ethical concern in vegetarians, which provided a foundation for their dietary choices. One exception was statement 8 for which there were no significant differences between vegetarians and others, nor for if they knew anyone who was. For this question the percentage of respondents who selected "never or rarely true” was quite high across all three categories. This suggests that truth in advertising was viewed as high priority regardless of dietary choice or connection to a vegetarian.

There were significant differences between those who self-reported as vegan or had a household member who was and those who were neither vegan, nor knew someone who was on all statements except 2, 4 and 7 . However, on these three statements, significant differences were still observed between those who reported having a close friend or family member who was vegan and those who were not vegan and did not know anyone who was. Those who self-reported as vegan or had a household member who was, selected "always or sometimes true" most often to every statement. Likewise, those who reported that a close friend or family member was vegan 
Table 4. Relationships between dietary preferences and social responsibility (\% of respondents) ${ }^{5}$.

\begin{tabular}{|c|c|c|c|c|c|c|}
\hline \multirow[b]{2}{*}{ Ethical Statement } & \multicolumn{3}{|c|}{ Vegetarian $^{6}$} & \multicolumn{3}{|c|}{ Vegan $^{7}$} \\
\hline & $\begin{array}{l}\text { I or a member } \\
\text { of my } \\
\text { household is. } \\
\text { (a) }\end{array}$ & $\begin{array}{l}\text { A close friend } \\
\text { or family } \\
\text { member is. } \\
\text { (b) }\end{array}$ & $\begin{array}{l}\text { No, neither I } \\
\text { nor anyone I } \\
\text { know is. } \\
\text { (c) }\end{array}$ & $\begin{array}{l}\text { I or a member } \\
\text { of my } \\
\text { household is. } \\
\text { (A) }\end{array}$ & $\begin{array}{l}\text { A close friend } \\
\text { or family } \\
\text { member is. } \\
\text { (B) }\end{array}$ & $\begin{array}{l}\text { No, neither I } \\
\text { nor anyone I } \\
\text { know is. } \\
\text { (C) }\end{array}$ \\
\hline $\begin{array}{l}\text { When I have a choice between } \\
\text { two equal products, I always } \\
\text { purchase the one that is less } \\
\text { harmful to the environment. }\end{array}$ & $76.2^{\mathrm{c}}$ & $76.9^{c}$ & $58.2^{\mathrm{a}, \mathrm{b}}$ & $75.0^{\mathrm{C}}$ & $77.9^{\mathrm{C}}$ & $60.0^{\mathrm{A}, \mathrm{B}}$ \\
\hline $\begin{array}{l}\text { I try to buy products that can } \\
\text { be recycled. }\end{array}$ & $79.6^{\mathrm{c}}$ & $83.0^{c}$ & $64.3^{\mathrm{a}, \mathrm{b}}$ & 72.4 & $77.9^{\mathrm{C}}$ & $66.3^{\mathrm{B}}$ \\
\hline $\begin{array}{l}\text { When there is a choice, I } \\
\text { always choose the product } \\
\text { which contributes to the } \\
\text { least amount of pollution. }\end{array}$ & $72.1_{\mathrm{c}}$ & $70.1_{\mathrm{c}}$ & $53.2_{\mathrm{a}, \mathrm{b}}$ & $75.0_{\mathrm{C}}$ & $69.5_{\mathrm{C}}$ & $55.4_{\mathrm{A}, \mathrm{B}}$ \\
\hline $\begin{array}{l}\text { Whenever possible, I buy } \\
\text { products packaged in } \\
\text { reusable containers. }\end{array}$ & $71.4^{\mathrm{c}}$ & $73.5^{\mathrm{c}}$ & $57.2^{\mathrm{a}, \mathrm{b}}$ & 65.8 & $75.8^{\mathrm{C}}$ & $58.8^{\mathrm{B}}$ \\
\hline $\begin{array}{l}\text { I have convinced members of } \\
\text { my family or friends not to buy } \\
\text { some products which are } \\
\text { harmful to the environment. }\end{array}$ & $61.2^{\mathrm{b}, \mathrm{c}}$ & $44.2^{\mathrm{a}, \mathrm{c}}$ & $31.8^{\mathrm{a}, \mathrm{b}}$ & $64.5^{\mathrm{C}}$ & $52.6^{\mathrm{C}}$ & $32.1^{\mathrm{A}, \mathrm{B}}$ \\
\hline $\begin{array}{l}\text { I make a conscious effort to } \\
\text { limit my use of products } \\
\text { that are made of or use } \\
\text { scarce resources. }\end{array}$ & $70.1^{\mathrm{c}}$ & $63.9^{c}$ & $48.3^{\mathrm{a}, \mathrm{b}}$ & $73.7^{\mathrm{C}}$ & $67.4^{\mathrm{C}}$ & $49.0^{\mathrm{A}, \mathrm{B}}$ \\
\hline $\begin{array}{l}\text { I do not buy products with } \\
\text { advertising that depicts } \\
\text { minority groups in a } \\
\text { negative way. }\end{array}$ & $72.8^{\mathrm{c}}$ & $64.6^{\mathrm{c}}$ & $50.4^{\mathrm{a}, \mathrm{b}}$ & $69.7^{\mathrm{C}}$ & $67.4^{\mathrm{C}}$ & $51.2^{\mathrm{A}, \mathrm{B}}$ \\
\hline $\begin{array}{l}\text { I do not buy a product that uses } \\
\text { deceptive advertising. }\end{array}$ & 74.1 & $80.3^{c}$ & $66.1^{\mathrm{b}}$ & 67.1 & $80.0^{\mathrm{C}}$ & $68.2^{\mathrm{B}}$ \\
\hline $\begin{array}{l}\text { I do not buy products from } \\
\text { companies involved in a } \\
\text { labor dispute. }\end{array}$ & $56.5^{\mathrm{b}, \mathrm{c}}$ & $36.7^{\mathrm{a}}$ & $33.4^{\mathrm{a}}$ & $59.2^{\mathrm{C}}$ & $47.4^{\mathrm{C}}$ & $33.2^{\mathrm{A}, \mathrm{B}}$ \\
\hline $\begin{array}{l}\text { I do not buy meat or milk } \\
\text { because of the conditions } \\
\text { under which the workers } \\
\text { who produce them } \\
\text { live and work. }\end{array}$ & $55.8^{\mathrm{b}, \mathrm{c}}$ & $29.3^{\mathrm{a}}$ & $25.3^{\mathrm{a}}$ & $53.9^{\mathrm{B}, \mathrm{C}}$ & $31.6^{\mathrm{A}}$ & $25.8^{\mathrm{A}}$ \\
\hline $\begin{array}{l}\text { I try to purchase from } \\
\text { companies who make } \\
\text { donations to charity. }\end{array}$ & $72.8^{\mathrm{b}, \mathrm{c}}$ & $51.7^{\mathrm{a}}$ & $46.6^{\mathrm{a}}$ & $63.2^{\mathrm{C}}$ & $62.1^{\mathrm{C}}$ & $47.6^{\mathrm{A}, \mathrm{B}}$ \\
\hline $\begin{array}{l}\text { I actively look to purchase } \\
\text { milk products which } \\
\text { promote welfare-friendly } \\
\text { conditions for the livestock } \\
\text { animals used to produce them. }\end{array}$ & $70.1^{\mathrm{b}, \mathrm{c}}$ & $49.0^{\mathrm{a}}$ & $42.1^{\mathrm{a}}$ & $71.1^{\mathrm{B}, \mathrm{C}}$ & $51.6^{\mathrm{A}}$ & $42.9^{\mathrm{A}}$ \\
\hline $\begin{array}{l}\text { I do not purchase eggs } \\
\text { produced from hens } \\
\text { housed in contentious } \\
\text { conditions. }\end{array}$ & $67.3^{\mathrm{b}, \mathrm{c}}$ & $44.9^{\mathrm{a}}$ & $36.7^{\mathrm{a}}$ & $68.4^{\mathrm{B}, \mathrm{C}}$ & $52.6^{\mathrm{A}, \mathrm{C}}$ & $37.0^{\mathrm{A}, \mathrm{B}}$ \\
\hline
\end{tabular}




\section{Continued}

\begin{tabular}{|c|c|c|c|c|c|c|}
\hline $\begin{array}{l}\text { I do not buy dairy products } \\
\text { produced on dairy farms that } \\
\text { use hormone supplements. }\end{array}$ & $76.2^{\mathrm{b}, \mathrm{c}}$ & $55.8^{\text {a.c }}$ & $43.3^{\mathrm{a} . \mathrm{b}}$ & $69.7^{\mathrm{C}}$ & $60.0^{\mathrm{C}}$ & $45.3^{\mathrm{A}, \mathrm{B}}$ \\
\hline $\begin{array}{l}\text { I do not buy meat products } \\
\text { from farms that do not allow } \\
\text { the cattle access to pasture. }\end{array}$ & $72.1^{\mathrm{b}, \mathrm{c}}$ & $47.6^{\text {a.c }}$ & $34.2^{\mathrm{a} . \mathrm{b}}$ & $63.2^{\mathrm{C}}$ & $52.6^{\mathrm{C}}$ & $35.5^{\mathrm{A}, \mathrm{B}}$ \\
\hline
\end{tabular}

${ }^{5}$ For brevity, this table has been shortened to include only the "always or sometimes true" percentages for each category. For example, of the male participants indicating "I or a member of my household is" vegetarian, for the ethical statement "I try to buy products that can be recycled" $79.6 \%$ claim the statement always or sometimes true of their practices, while the remaining $20.4 \%$ of male participants claim the statement is never or rarely true of their personal practices. ${ }^{6}$ Significant differences are noted by a, b, c. ${ }^{7}$ Significant differences are noted by A, B, C.

responded “always or sometimes true” most often to every statement except 9 and 10 .

On the statements that pertained to animal welfare, a majority of those who identified as vegetarian or vegan and those who had a member of the household who was vegan responded "always or sometimes true”. Although the survey did not inquire about the reasons for vegetarians' or vegans' dietary choices, it would not be surprising if they were due at least in part to concerns for animal welfare. This hypothesis is somewhat supported by Vanhonacker et al. (2007) who reported that heavy meat consumers were less concerned about animal welfare than individuals reporting moderate or low meat consumption. It is logical that those reporting low or no meat consumption might be more concerned about animal welfare than those who consumed more.

A majority of those who identified as vegetarian or vegan also tended to select "always or sometimes true" in response to the ethical statements that pertained to environmental protection via recycling. These data are consistent with Fox and Ward's (2008) findings that in addition to having strong concerns about animal welfare, vegetarians also were very concerned about the environment, even if environmental issues were not their main reason for their choice of diet. Siegrist et al. (2015) similarly reported that people's motivations behind dietary choices such as health or other concerns can impact their consideration of environmental factors associated with the foods they choose.

\subsection{Travel, Volunteerism, and Charitable Donations}

Travel

The role of travel abroad in shaping underlying beliefs about personal social responsibility was explored in this study. Respondents were asked whether they had traveled outside of the US within the past 5 years and for what reason (Table 5). The majority of participants (67\%) had not traveled abroad. Of the 33\% that had traveled outside the US in the past 5 years, the majority traveled for vacation (81\%). Table 6 displays cross-tabulation results of respondents' travel and responses to consumption-related statements. Those who had traveled responded significantly differently from those who had not on all statements except statements 4, 8 and 10. One must consider whether travel itself, and exposure to different cultural and social norms and beliefs, influences people's ideas about social responsibility. Alternatively, it is possible that those who travel abroad are already more inclined toward certain aspects of personal social responsibility. While the current study does not inform conclusions as to which explanation (or the extent to which both) might be correct, some insights can be gleaned from studies focused on cross-cultural and cross-national differences in ethical beliefs and behaviors. For example, Nyaw and Ng (1994) reported differences in students' responses to ethical dilemmas as a function of national origin, suggesting that various factors including cultural, familial, societal and legal norms play a role in shaping ethical beliefs and their international variations. Likewise, Auger et al. (2007) reported cross-country variation in consumers' responses to social and ethical issues, while others have pointed out the existence of cultural as well as individual differences on different dimensions of values (Maignan, 2001; Schwartz, 1992).

Both travelers and non-travelers showed low agreement with statement 10 by most often selecting "never or rarely true”. In addition to the possibility that concern for workers involved in meat and milk production is low, the possibility exists that people do not believe there are adverse conditions experienced by the workers, or that they are possibly unaware of these conditions. In contrast, there was high agreement indicated by responding "always or sometimes true" to statement 8. Apparently, truth in advertising is a shared value for travelers and non-travelers alike, which is consistent with findings by Darke (2007) who noted that deceptive advertising 
Table 5. Travel experiences outside the US.

\begin{tabular}{cc}
\hline Variable description & Survey \\
\cline { 2 - 2 } Yes & Frequency (\%) \\
No & 33 \\
Traveled abroad in past 5 years (n = 1201) & 67 \\
Reason for travel (n = 401) & \\
Vacation & 81 \\
Missions work & 4 \\
Religious Pilgrimage & 3 \\
Volunteer work & 2 \\
Work-related business & 6 \\
School-related business & 2 \\
Other & 2 \\
\hline
\end{tabular}

creates distrust and negative bias in consumers that undermines future advertising efforts. Those traveling for mission-related work responded "always or sometimes true" more often for every statement and generally appeared to differ in their responses from those who traveled for all other reasons. This group of respondents had the highest percentage (86.7\%) of agreement of any demographic, with statement 10 . It is plausible that those who travel for mission-related work are more socially conscious and therefore more apt to be concerned about potentially adverse working and living conditions for workers employed in meat or milk production. However, the possibility that these respondents may have relatively high social desirability bias in their reporting of agreement with the various statements should also be considered.

Throughout this study, the percentage of respondents selecting "always or sometimes true" in response to statement 10 was quite low given that previous studies have reported strong consumer response to employee treatment as an ethical concern (Cowe \& Williams, 2000; Galavielle, 2004). However, consistent with our findings, Carrigan and Attalla (2001) observed low prioritization of worker treatment by consumers on issues such as working conditions. Nonetheless, the possibility that mission-related travelers may have higher than average CSR expectations for socio-ethical dimensions, including worker conditions, may be of importance to companies, particularly those marketing products or services to such travelers.

\subsection{Volunteerism}

The extent to which consumers participate in volunteer activities and the effects these might have in motivating personal social responsibility as well as views of CSR were another area of interest. In this survey, $48 \%$ of respondents reported volunteering in the past 5 years, with the majority (63\%) noting that they did so to give back to their communities (Table 7).

There were significant differences between those who volunteered and those who did not in the responses to every statement, with volunteers consistently selecting "always or sometimes true" for all of the personal responsibility statements (Table 8). On statements 2 and 8, the percentage of those responding "always or sometimes true" in regards to their own practices was particularly high. As has been observed throughout, on statement 10 , the percentage of those who responded with "always or sometimes true" was low (33.8\%), and lower for those who did not volunteer (26.4\%).

\subsection{Charitable Donations}

Those who personally donate to charities may expect corporations to do likewise as a component of CSR. According to Carroll's (1991) pyramid of social responsibility, corporate philanthropic activity is at the top of the pyramid in that it is desired as a component of good citizenry but is not expected or required. However, recent 
Table 6. Relationships between participant travel and "always or sometimes true” response to ethical inquiry (\% of respondents) $)^{8}$.

\begin{tabular}{|c|c|c|c|c|c|c|c|c|c|}
\hline \multirow{2}{*}{ Ethical statement } & \multicolumn{2}{|c|}{$\begin{array}{l}\text { Have you traveled } \\
\text { abroad (outside the } \\
\text { US) in the past } 5 \\
\text { years? }\end{array}$} & \multicolumn{7}{|c|}{ What was the main purpose of the majority of your travels? ${ }^{10}$} \\
\hline & $\begin{array}{l}\text { Yes } \\
\text { (a) }\end{array}$ & $\begin{array}{l}\text { No } \\
\text { (b) }\end{array}$ & $\begin{array}{l}\text { Vacation } \\
\text { (A) }\end{array}$ & $\begin{array}{l}\text { Missions } \\
\text { work } \\
\text { (B) }\end{array}$ & $\begin{array}{l}\text { Religious } \\
\text { pilgrimage } \\
\text { (C) }\end{array}$ & $\begin{array}{l}\text { Volunteer } \\
\text { work } \\
\text { (D) }\end{array}$ & $\begin{array}{l}\text { Work-related } \\
\text { business } \\
\text { (E) }\end{array}$ & $\begin{array}{l}\text { School-rel } \\
\text { ated travel } \\
\text { (F) }\end{array}$ & $\begin{array}{l}\text { Other } \\
\text { (G) }\end{array}$ \\
\hline $\begin{array}{l}\text { When I have a choice between } \\
\text { two equal products, I always } \\
\text { purchase the one that is less } \\
\text { harmful to the environment. }\end{array}$ & $72.3^{\mathrm{b}}$ & $58.4^{\mathrm{a}}$ & 71.2 & 86.7 & 90.9 & 71.4 & 69.2 & 83.3 & 70.0 \\
\hline $\begin{array}{l}\text { I try to buy products that } \\
\text { can be recycled. }\end{array}$ & $74.3^{\mathrm{b}}$ & $65.6^{\mathrm{a}}$ & 73.6 & 80.0 & 81.8 & 71.4 & 73.1 & 83.3 & 80.0 \\
\hline $\begin{array}{l}\text { When there is a choice, I } \\
\text { always choose the product } \\
\text { which contributes to the least } \\
\text { amount of pollution. }\end{array}$ & $64.6^{\mathrm{b}}$ & $55.1^{\mathrm{a}}$ & 63.8 & 66.7 & $90.9^{\mathrm{D}, \mathrm{G}}$ & $42.9^{\mathrm{C}}$ & 73.1 & 66.7 & $50.0^{\mathrm{C}}$ \\
\hline $\begin{array}{l}\text { Whenever possible, I buy } \\
\text { products packaged in } \\
\text { reusable containers. }\end{array}$ & 65.1 & 59.2 & 63.5 & 73.3 & 72.7 & 71.4 & 65.4 & 100.0 & 70.0 \\
\hline $\begin{array}{l}\text { I have convinced members of } \\
\text { my family or friends not to buy } \\
\text { some products which are } \\
\text { harmful to the environment. }\end{array}$ & $45.1^{\mathrm{b}}$ & $33.5^{\mathrm{a}}$ & $45.1^{\mathrm{B}}$ & $73.3^{\mathrm{A}, \mathrm{F}, \mathrm{G}}$ & 54.5 & 42.9 & 42.3 & $16.7^{\mathrm{B}}$ & $20.0^{\mathrm{B}}$ \\
\hline $\begin{array}{l}\text { I make a conscious effort to } \\
\text { limit my use of products } \\
\text { that are made of or use } \\
\text { scarce resources. }\end{array}$ & $63.6^{\mathrm{b}}$ & $48.3^{\mathrm{a}}$ & 63.5 & 66.7 & $81.8^{\mathrm{F}}$ & 57.1 & 65.4 & $33.3^{C}$ & 60.0 \\
\hline $\begin{array}{l}\text { I do not buy products with } \\
\text { advertising that depicts } \\
\text { minority groups in a } \\
\text { negative way. }\end{array}$ & $61.8^{\mathrm{b}}$ & $52.4^{\mathrm{a}}$ & $60.1^{\mathrm{B}, \mathrm{F}}$ & $86.7^{\mathrm{A}}$ & $54.5^{\mathrm{F}}$ & 71.4 & $57.7^{\mathrm{F}}$ & $100.0^{\mathrm{A}, \mathrm{C}, \mathrm{E}}$ & 70.0 \\
\hline $\begin{array}{l}\text { I do not buy a product that } \\
\text { uses deceptive advertising. }\end{array}$ & 71.3 & 67.5 & 72.4 & 80.0 & 72.7 & 57.1 & 61.5 & 66.7 & 60.0 \\
\hline $\begin{array}{l}\text { I do not buy products from } \\
\text { companies involved in a } \\
\text { labor dispute. }\end{array}$ & $42.6^{\mathrm{b}}$ & $33.9^{\mathrm{a}}$ & $40.2^{\mathrm{B}, \mathrm{F}}$ & $66.7^{\mathrm{A}, \mathrm{D}}$ & 54.5 & $14.3^{\mathrm{B}, \mathrm{F}, \mathrm{G}}$ & 42.3 & $83.3^{\mathrm{A}, \mathrm{D}}$ & $70.0^{\mathrm{D}}$ \\
\hline $\begin{array}{l}\text { I do not buy meat or milk } \\
\text { because of the conditions under } \\
\text { which the workers who } \\
\text { produce them live and work. }\end{array}$ & 33.2 & 28.4 & $31.9^{\mathrm{B}}$ & $86.7^{\mathrm{A}, \mathrm{C}, \mathrm{D}, \mathrm{E}, \mathrm{F}, \mathrm{G}}$ & $27.3^{\mathrm{B}}$ & $28.6^{\mathrm{B}}$ & $34.6^{\mathrm{B}}$ & $16.7^{\mathrm{B}}$ & $10.0^{\mathrm{B}}$ \\
\hline $\begin{array}{l}\text { I try to purchase from } \\
\text { companies who make } \\
\text { donations to charity. }\end{array}$ & $57.1^{\mathrm{b}}$ & $47.5^{\mathrm{a}}$ & 56.1 & 73.3 & 63.6 & 57.1 & 53.8 & 83.3 & 50.0 \\
\hline $\begin{array}{l}\text { I actively look to purchase } \\
\text { milk products which } \\
\text { promote welfare-friendly } \\
\text { conditions for the livestock } \\
\text { animals used to produce them. }\end{array}$ & $54.4^{\mathrm{b}}$ & $43.4^{\mathrm{a}}$ & $54.0^{\mathrm{B}}$ & $80.0^{\mathrm{A}, \mathrm{D}, \mathrm{G}}$ & 54.5 & $28.6^{\mathrm{A}, \mathrm{D}, \mathrm{G}}$ & 53.8 & 66.7 & $40.0^{\mathrm{A}, \mathrm{D}, \mathrm{G}}$ \\
\hline
\end{tabular}




\begin{tabular}{|c|c|c|c|c|c|c|c|c|c|}
\hline \multicolumn{10}{|l|}{ Continued } \\
\hline $\begin{array}{l}\text { I do not purchase eggs } \\
\text { produced from hens housed } \\
\text { in contentious conditions. }\end{array}$ & $48.4^{\mathrm{b}}$ & $38.9^{\mathrm{a}}$ & $49.1^{\mathrm{B}}$ & $80.0^{\mathrm{A}, \mathrm{C}, \mathrm{D}, \mathrm{E}, \mathrm{G}}$ & $36.4^{\mathrm{B}}$ & $14.3^{\mathrm{B}}$ & $42.3^{\mathrm{B}}$ & $66.7^{\mathrm{B}}$ & $20.0^{\mathrm{B}}$ \\
\hline $\begin{array}{l}\text { I do not buy dairy products } \\
\text { produced on dairy farms that } \\
\text { use hormone supplements. }\end{array}$ & $53.9^{\mathrm{b}}$ & $46.7^{\mathrm{a}}$ & $53.4^{\mathrm{B}, \mathrm{D}}$ & $93.3^{\mathrm{A}, \mathrm{D}, \mathrm{E}, \mathrm{F}, \mathrm{G}}$ & $72.7^{\mathrm{D}}$ & $14.3^{\mathrm{A}, \mathrm{B}, \mathrm{C}}$ & $53.8^{\mathrm{B}}$ & $33.3^{\mathrm{B}}$ & $30.0^{\mathrm{B}}$ \\
\hline $\begin{array}{l}\text { I do not buy meat products } \\
\text { from farms that do not allow } \\
\text { the cattle access to pasture. }\end{array}$ & $46.6^{\mathrm{b}}$ & $37.7^{\mathrm{a}}$ & 46.3 & $66.7^{\mathrm{G}}$ & $63.6^{\mathrm{G}}$ & 28.6 & 50.0 & 33.3 & $20.0^{\mathrm{B}, \mathrm{C}}$ \\
\hline
\end{tabular}

${ }^{8}$ For brevity, this table has been shortened to include only the "always or sometimes true" percentages of the response for each category. This can be interpreted for the statement "I try to buy products that can be recycled" as $74.3 \%$ of those who have traveled outside the U.S. in the past 5 years claim the statement is always or sometimes true of their behavior, while $25.7 \%$ of those who have traveled abroad claim the statements is never or rarely true of their behavior. ${ }^{9}$ Significant differences are noted by a, b. ${ }^{10}$ Significant differences are noted by A, B, C, D, E, F, G.

\section{Table 7. Volunteerism.}

Variable description

\begin{tabular}{lcc}
\hline Variable description & Survey \\
\cline { 2 - 2 }
\end{tabular}

Volunteered in past 5 years $(n=1201)$

Yes

No

48

52

Reason for volunteering $(n=580)$

Requirement to log a certain number of volunteer hours

Social activity with family and friends

Give back to the community

Other
10

20

63

7

studies suggest that consumers' CSR expectations are more closely tied to responsibilities outside of economic performance (Maignan, 2001; Matten \& Moon, 2005). For example, Golob et al. (2008) reported that consumers have increasingly high CSR expectations relative to ethical/philanthropic action. Therefore the extent to which respondents donated to charitable organizations, their reasons for doing so and the nature of the charities selected were explored.

Fifty-four percent of respondents reported that they regularly donated to charities. The vast majority (81\%) selected "I believe giving ultimately benefits the charities and people they serve" as their primary reason for giving. For domestic charities, respondents primarily gave to churches or religious organizations, food pantries, human health or adult/child welfare organizations. Those donating to international charities most frequently supported adult/child welfare, human health and church or religious organizations (Table 9).

On every statement pertaining to the ethical inquiry, those who donated to charity, responded significantly differently from those who did not, more often selecting “always or sometimes true” (Table 10). The percentage of respondents selecting "always or sometimes true” was highest for those who donated on statements 1 , and 8 , and was lowest on statement 10 . Interestingly, while there were also differences on statement 11 , the percentage of charitable donors selecting “always or sometimes true” was not particularly high (59.7\%).

Those who donated because another organization, church or business they were involved with encouraged them to do so consistently differed from those who donated for other reasons. The only exception to this pattern was on statements 1 and 4 where no differences were evident across any of the categories. Those who felt compelled to give by family and friends had the highest percentage of "always or sometimes true" responses to 10 of the 15 ethical statements. They were notably higher in selecting this response (54.1\%) to statement 10 and also on all of the environmental and animal welfare statements, as well as the fair labor-related and corporate charitable giving statements. These latter findings are intriguing, as in concert with the result that those who donate regularly to charities respond differently from those who do not, they raise the question as to whether charitable 
Table 8. Relationships between participant volunteerism and “always or sometimes true” response to ethical inquiry (\% of respondents) $)^{11}$.

\begin{tabular}{|c|c|c|c|c|c|c|}
\hline \multirow[b]{2}{*}{ Ethical statement } & \multicolumn{2}{|c|}{$\begin{array}{l}\text { Have you volunteered in } \\
\text { the past } 5 \text { years? }\end{array}$} & \multicolumn{4}{|c|}{ What is the main reason you volunteer? ${ }^{13}$} \\
\hline & $\begin{array}{l}\text { Yes } \\
\text { (a) }\end{array}$ & $\begin{array}{l}\text { No } \\
\text { (b) }\end{array}$ & $\begin{array}{c}\text { Requirement to } \log \text { a } \\
\text { certain number of } \\
\text { volunteer hours (A) }\end{array}$ & $\begin{array}{l}\text { Social activity with } \\
\text { family and friends } \\
\text { (B) }\end{array}$ & $\begin{array}{l}\text { Give back to } \\
\text { the community } \\
\text { (C) }\end{array}$ & $\begin{array}{l}\text { Other } \\
\text { (D) }\end{array}$ \\
\hline $\begin{array}{l}\text { When I have a choice between } \\
\text { two equal products, I always } \\
\text { purchase the one that is less } \\
\text { harmful to the environment. }\end{array}$ & $70.0^{\mathrm{b}}$ & $56.5^{\mathrm{a}}$ & $52.5^{\mathrm{B}}$ & $73.1^{\mathrm{A}}$ & $72.5^{\mathrm{A}}$ & 64.1 \\
\hline $\begin{array}{l}\text { I try to buy products that can } \\
\text { be recycled }\end{array}$ & $76.0^{\mathrm{b}}$ & $61.5^{\mathrm{a}}$ & $67.8^{\mathrm{C}}$ & 72.3 & $79.9^{\mathrm{A}}$ & $64.1^{\mathrm{C}}$ \\
\hline $\begin{array}{l}\text { When there is a choice, I always } \\
\text { choose the product which contributes } \\
\text { to the least amount of pollution. }\end{array}$ & $64.8^{\mathrm{b}}$ & $52.2^{\mathrm{a}}$ & 55.9 & 67.2 & 66.9 & 51.3 \\
\hline $\begin{array}{l}\text { Whenever possible, I buy products } \\
\text { packaged in reusable containers. }\end{array}$ & $69.0^{\mathrm{b}}$ & $53.9^{\mathrm{a}}$ & $59.3^{\mathrm{C}}$ & 63.9 & $72.7^{\mathrm{A}}$ & 64.1 \\
\hline $\begin{array}{l}\text { I have convinced members of my } \\
\text { family or friends not to buy some } \\
\text { products which are harmful } \\
\text { to the environment. }\end{array}$ & $44.1^{\mathrm{b}}$ & $31.1^{\mathrm{a}}$ & $47.5^{\mathrm{D}}$ & $52.9^{\mathrm{D}}$ & $43.5^{\mathrm{D}}$ & $17.9^{\mathrm{A}, \mathrm{B}, \mathrm{C}}$ \\
\hline $\begin{array}{l}\text { I make a conscious effort to limit } \\
\text { my use of products that are made of } \\
\text { or use scarce resources. }\end{array}$ & $59.8^{\mathrm{b}}$ & $47.3^{\mathrm{a}}$ & 59.3 & 59.7 & 61.2 & 48.7 \\
\hline $\begin{array}{l}\text { I do not buy products with advertising } \\
\text { that depicts minority groups in a } \\
\text { negative way. }\end{array}$ & $62.8^{\mathrm{b}}$ & $48.8^{\mathrm{a}}$ & 59.3 & 63.9 & $64.7^{\mathrm{D}}$ & $46.2^{\mathrm{C}}$ \\
\hline $\begin{array}{l}\text { I do not buy a product that uses } \\
\text { deceptive advertising. }\end{array}$ & $77.1^{\mathrm{b}}$ & $61.0^{\mathrm{a}}$ & $66.1^{\mathrm{C}}$ & 74.8 & $79.3^{\mathrm{A}}$ & 79.5 \\
\hline $\begin{array}{l}\text { I do not buy products from } \\
\text { companies involved in a } \\
\text { labor dispute. }\end{array}$ & $40.3^{b}$ & $33.5^{\mathrm{a}}$ & 39.0 & $50.4^{\mathrm{C}, \mathrm{D}}$ & $38.3^{\mathrm{B}}$ & $30.8^{\mathrm{B}}$ \\
\hline $\begin{array}{l}\text { I do not buy meat or milk because } \\
\text { of the conditions under which } \\
\text { the workers who produce them } \\
\text { live and work. }\end{array}$ & $33.8^{\mathrm{b}}$ & $26.4^{\mathrm{a}}$ & $50.8^{\mathrm{C}, \mathrm{D}}$ & $40.3^{\mathrm{D}}$ & $30.9^{\mathrm{A}, \mathrm{D}}$ & $15.4^{\mathrm{A}, \mathrm{B}, \mathrm{C}}$ \\
\hline $\begin{array}{l}\text { I try to purchase from companies } \\
\text { who make donations to charity. }\end{array}$ & $58.4^{\mathrm{b}}$ & $43.5^{\mathrm{a}}$ & $57.6^{\mathrm{D}}$ & $58.0^{\mathrm{D}}$ & $61.2^{\mathrm{D}}$ & $35.9^{\mathrm{A}, \mathrm{B}, \mathrm{C}}$ \\
\hline $\begin{array}{l}\text { I actively look to purchase milk } \\
\text { products which promote } \\
\text { welfare-friendly conditions for } \\
\text { the livestock animals used to } \\
\text { produce them. }\end{array}$ & $51.0^{\mathrm{b}}$ & $43.3^{\mathrm{a}}$ & $49.2^{\mathrm{D}}$ & $56.3^{\mathrm{D}}$ & $52.3^{\mathrm{D}}$ & $25.6^{\mathrm{A}, \mathrm{B}, \mathrm{C}}$ \\
\hline $\begin{array}{l}\text { I do not purchase eggs produced } \\
\text { from hens housed in } \\
\text { contentious conditions. }\end{array}$ & $46.0^{\mathrm{b}}$ & $38.3^{\mathrm{a}}$ & $52.5^{\mathrm{D}}$ & $47.1^{\mathrm{D}}$ & $46.6^{\mathrm{D}}$ & $28.2^{A, B, C}$ \\
\hline $\begin{array}{l}\text { I do not buy dairy products } \\
\text { produced on dairy farms that } \\
\text { use hormone supplements. }\end{array}$ & $54.0^{\mathrm{b}}$ & $44.6^{\mathrm{a}}$ & 59.3 & 55.5 & 53.2 & 48.7 \\
\hline $\begin{array}{l}\text { I do not buy meat products from } \\
\text { farms that do not allow the } \\
\text { cattle access to pasture. }\end{array}$ & $45.5^{\mathrm{b}}$ & $36.2^{\mathrm{a}}$ & $50.8^{\mathrm{D}}$ & 47.9 & 45.5 & $30.8^{\mathrm{A}}$ \\
\hline
\end{tabular}

\footnotetext{
${ }^{11}$ For brevity, this table has been shortened to include only the "always or sometimes true" percentages for each category. This can be interpreted for the statement "I try to buy products that can be recycled" as $76.0 \%$ of those who have volunteered in the past 5 years claim the statement is always or sometimes true of their behavior, while $24.0 \%$ of those who have traveled abroad claim the statements is never or rarely true of their behavior. ${ }^{12}$ Significant differences are noted by a, b. ${ }^{13}$ Significant differences are noted by A, B, C, D.
} 
Table 9. Charitable giving.

\section{Variable description}

Survey

Frequency (\%)

Donate regularly to charities $(n=1201)$

Yes

No
54

46

Reason for donating to charities $(n=652)$

I believe giving ultimately benefits the charities and people that they serve.

I feel compelled by family and friends who also give to charities.

Another organization, church, or business I am involved with encourages me to give to charity.

Other

Types of charities given to $(n=652$ people; 2050 total responses for domestic and 530 for international)

Church or religious organizations

Environmental

Animal-welfare

Human health

Adult and/or child welfare

Educational

Food pantry

Other

6

9

4
Domestic

20

9

12

14

14

10

16

5
International

14

12

12

17

16

11

10

7

giving inspires greater overall ethical behavior or whether much of what appears to be ethically motivated behavior is in fact the result of social compulsion. Regardless, if some respondents felt compelled to behave ethically as a function of social pressure, it is likely that they might believe either that corporations should also feel compelled to act responsibly or that CSR activities may likewise be due to compulsion rather than altruism. Both explanations have CSR implications, with the first providing additional support for the need for corporations to consider their socio-ethical alignment with that of their consumers (Auger et al., 2007), and the other supporting the idea that some CSR initiatives may appear to be solely strategic, and thus, met with a degree of skepticism by some consumers as discussed by Skarmeas and Lenidou (2013).

\section{Conclusions}

This study builds on existing research linking consumer social responsibility behaviors to key demographics and suggests that underlying associated values, beliefs and knowledge may hold potential implications for CSR expectations. As observed by Roberts (1995), our findings indicated that many respondents frequently engaged in socially responsible consumer behaviors, appearing to avoid purchasing some products that were perceived to do harm (e.g., those that negatively portrayed minorities in their advertisements and those that use deceptive advertising) and indicating a preference for buying products that appeared to support environmental integrity, animal welfare and corporate philanthropy. Women, younger respondents, and those with advanced degrees consistently appeared to be more sensitive to these issues, with the only major difference in our findings compared to others being that those with advanced degrees were not significantly more concerned about animal welfare than those with less education. Particularly notable differences were evident between men and women on the environmental issues as reported by others (Roberts, 1996; Schwartz \& Miller, 1991; Wandel \& Bugge, 1997). Likewise, our findings that vegetarians and vegans expressed high concern for both animal welfare and environmental protection resembled those of previous studies (Fox \& Ward, 2008). 
Table 10. Relationships between participant charitable giving and "always or sometimes true” responses to ethical inquiry (\% of respondents) ${ }^{14}$.

\begin{tabular}{|c|c|c|c|c|c|c|c|c|c|c|}
\hline \multirow[b]{3}{*}{ Ethical Statement } & \multicolumn{2}{|c|}{$\begin{array}{c}\text { Do you regularly } \\
\text { donate to } \\
\text { charities? }^{15}\end{array}$} & \multicolumn{4}{|c|}{ Why do you give to charities? ${ }^{16}$} & \multicolumn{4}{|c|}{$\begin{array}{l}\text { What type of charities do you } \\
\text { give to }{ }^{17,18}\end{array}$} \\
\hline & \multirow[b]{2}{*}{$\begin{array}{l}\text { Yes } \\
\left({ }^{*}\right)\end{array}$} & \multirow[b]{2}{*}{$\begin{array}{l}\text { No } \\
\left({ }^{* *}\right)\end{array}$} & \multirow{2}{*}{$\begin{array}{c}\text { I believe } \\
\text { giving } \\
\text { ultimately } \\
\text { benefits the } \\
\text { charities and } \\
\text { people they } \\
\text { serve. } \\
\text { (a) }\end{array}$} & \multirow{2}{*}{$\begin{array}{c}\text { I feel } \\
\text { compelled } \\
\text { by family } \\
\text { and friends } \\
\text { who also } \\
\text { give to } \\
\text { charities. } \\
\text { (b) }\end{array}$} & \multirow{2}{*}{$\begin{array}{l}\text { Another } \\
\text { organization, } \\
\text { church, or } \\
\text { business I am } \\
\text { involved in } \\
\text { encourages me } \\
\text { to give to } \\
\text { charity. } \\
\text { (c) }\end{array}$} & \multirow[b]{2}{*}{$\begin{array}{l}\text { Other } \\
\text { (d) }\end{array}$} & \multicolumn{2}{|c|}{ Domestic } & \multicolumn{2}{|c|}{ International } \\
\hline & & & & & & & $\begin{array}{l}\text { Yes } \\
\text { (A) }\end{array}$ & $\begin{array}{l}\text { No } \\
\text { (B) }\end{array}$ & $\begin{array}{l}\text { Yes } \\
(\alpha)\end{array}$ & $\begin{array}{l}\text { No } \\
(\beta)\end{array}$ \\
\hline $\begin{array}{l}\text { When I have a choice between } \\
\text { two equal products, I always } \\
\text { purchase the one that is less } \\
\text { harmful to the environment. }\end{array}$ & $71.5^{* *}$ & $53.0^{*}$ & 71.6 & 78.4 & 60.7 & 80.6 & $71.4^{\mathrm{B}}$ & $53.2^{\mathrm{A}}$ & $77.7^{\beta}$ & $59.2^{\alpha}$ \\
\hline $\begin{array}{l}\text { I try to buy products that } \\
\text { can be recycled. }\end{array}$ & $76.1^{* *}$ & $59.6^{*}$ & $77.3^{\mathrm{c}}$ & $81.1^{\mathrm{c}}$ & $58.9^{\mathrm{a}, \mathrm{b}, \mathrm{d}}$ & $80.6^{\mathrm{c}}$ & $76.2^{\mathrm{B}}$ & $59.6^{\mathrm{A}}$ & $77.3^{\beta}$ & $66.2^{\alpha}$ \\
\hline $\begin{array}{l}\text { When there is a choice, I always } \\
\text { choose the product which } \\
\text { contributes to the least } \\
\text { amount of pollution. }\end{array}$ & $64.6^{* *}$ & $50.8^{*}$ & 64.4 & $78.4^{\mathrm{c}}$ & $55.4^{\mathrm{b}}$ & 67.7 & $64.8^{\mathrm{B}}$ & $50.7^{\mathrm{A}}$ & $70.1^{\beta}$ & $55.2^{\alpha}$ \\
\hline $\begin{array}{l}\text { Whenever possible, I buy } \\
\text { products packaged in } \\
\text { reusable containers. }\end{array}$ & $67.8^{* *}$ & $53.4^{*}$ & 67.8 & 75.7 & 57.1 & 77.4 & $67.9^{\mathrm{B}}$ & $53.4^{\mathrm{A}}$ & $72.9^{\beta}$ & $58.1^{\alpha}$ \\
\hline $\begin{array}{l}\text { I have convinced members } \\
\text { of my family or friends } \\
\text { not to buy some products } \\
\text { which are harmful } \\
\text { to the environment. }\end{array}$ & $42.6^{* *}$ & $31.1^{*}$ & $43.7^{\mathrm{b}, \mathrm{c}}$ & $67.6^{\mathrm{a}, \mathrm{c}, \mathrm{d}}$ & $19.6^{\mathrm{a}, \mathrm{b}}$ & $35.5^{\mathrm{b}}$ & $42.7^{\mathrm{B}}$ & $31.2^{\mathrm{A}}$ & $52.2^{\beta}$ & $33.5^{\alpha}$ \\
\hline $\begin{array}{l}\text { I make a conscious effort } \\
\text { to limit my use of products } \\
\text { that are made of or use } \\
\text { scarce resources. }\end{array}$ & $59.4^{* *}$ & $46.3^{*}$ & $61.2^{\mathrm{c}}$ & $59.5^{c}$ & $35.7^{\mathrm{a}, \mathrm{b}, \mathrm{d}}$ & $71.0^{c}$ & $59.5^{\mathrm{B}}$ & $46.2^{\mathrm{A}}$ & $64.1^{\beta}$ & $50.5^{\alpha}$ \\
\hline $\begin{array}{l}\text { I do not buy products with } \\
\text { advertising that depicts minority } \\
\text { groups in a negative way. }\end{array}$ & $62.1^{* *}$ & $47.7^{*}$ & $63.8^{c}$ & 62.2 & $46.4^{\mathrm{a}}$ & 61.3 & $62.1^{\mathrm{B}}$ & $47.8^{\mathrm{A}}$ & $67.3^{\beta}$ & $52.4^{\alpha}$ \\
\hline $\begin{array}{l}\text { I do not buy a product that } \\
\text { uses deceptive advertising. }\end{array}$ & $75.9^{* *}$ & $60.3^{*}$ & $77.1^{\mathrm{c}}$ & 70.3 & $64.3^{\mathrm{a}}$ & 83.9 & $76.0^{\mathrm{B}}$ & $60.3^{\mathrm{A}}$ & $77.7^{\beta}$ & $66.4^{\alpha}$ \\
\hline $\begin{array}{l}\text { I do not buy products from } \\
\text { companies involved in } \\
\text { a labor dispute. }\end{array}$ & $41.3_{* *}$ & $31.5 *$ & 41.3 & $56.8_{\mathrm{c}}$ & $33.9_{\mathrm{b}}$ & 35.5 & $41.3_{\mathrm{B}}$ & $31.6_{\mathrm{A}}$ & $48.6_{\beta}$ & $33.7_{\alpha}$ \\
\hline $\begin{array}{l}\text { I do not buy meat or } \\
\text { milk because of the conditions } \\
\text { under which the workers who } \\
\text { produce them live and work. }\end{array}$ & $32.5^{* *}$ & $27.0^{*}$ & $32.8^{b}$ & $54.1^{\mathrm{a}, \mathrm{c}, \mathrm{d}}$ & $25.0^{\mathrm{b}}$ & $16.1^{\mathrm{b}}$ & $32.5^{\mathrm{B}}$ & $27.1^{\mathrm{A}}$ & $39.8^{\beta}$ & $27.4^{\alpha}$ \\
\hline $\begin{array}{l}\text { I try to purchase from } \\
\text { companies who make } \\
\text { donations to charity. }\end{array}$ & $59.7^{* *}$ & $40.1^{*}$ & $61.7^{\mathrm{c}}$ & 64.9 & $44.6^{\mathrm{a}}$ & 45.2 & $59.7^{\mathrm{B}}$ & $40.3^{\mathrm{A}}$ & $65.3^{\beta}$ & $46.8^{\alpha}$ \\
\hline $\begin{array}{l}\text { I actively look to purchase } \\
\text { milk products which promote } \\
\text { welfare-friendly conditions } \\
\text { for the livestock animals } \\
\text { used to produce them. }\end{array}$ & $52.1^{* *}$ & $51.0^{*}$ & $53.4^{\mathrm{b}, \mathrm{c}}$ & $75.7^{\mathrm{a}, \mathrm{c}, \mathrm{d}}$ & $28.6^{\mathrm{a}, \mathrm{b}}$ & $45.2^{\mathrm{b}}$ & $52.1^{\mathrm{B}}$ & $41.2^{\mathrm{A}}$ & $59.0^{\beta}$ & $43.9^{\alpha}$ \\
\hline
\end{tabular}




\begin{tabular}{|c|c|c|c|c|c|c|c|c|c|c|}
\hline \multicolumn{11}{|l|}{ Continued } \\
\hline $\begin{array}{l}\text { I do not purchase eggs } \\
\text { produced from hens } \\
\text { housed in } \\
\text { contentious conditions. }\end{array}$ & $46.2^{* *}$ & $37.2^{*}$ & $46.4^{\mathrm{b}, \mathrm{c}}$ & $64.9^{\mathrm{a}, \mathrm{c}}$ & $32.1^{\mathrm{a}, \mathrm{b}}$ & 45.2 & $46.2^{\mathrm{B}}$ & $37.2^{\mathrm{A}}$ & $56.2^{\beta}$ & $38.3^{\alpha}$ \\
\hline $\begin{array}{l}\text { I do not buy dairy products } \\
\text { produced on dairy farms that } \\
\text { use hormone supplements. }\end{array}$ & $54.1^{* *}$ & $43.2^{*}$ & $54.5^{c}$ & $64.9^{c}$ & $35.7^{\mathrm{a}, \mathrm{b}, \mathrm{d}}$ & $67.7^{\mathrm{c}}$ & $54.1^{\mathrm{B}}$ & $43.3^{\mathrm{A}}$ & $63.3^{\beta}$ & $45.4^{\alpha}$ \\
\hline $\begin{array}{l}\text { I do not buy meat products } \\
\text { from farms that do not allow } \\
\text { the cattle access to pasture. }\end{array}$ & $44.6^{* *}$ & $36.1^{*}$ & $44.7^{\mathrm{b}, \mathrm{c}}$ & $62.2^{\mathrm{a}, \mathrm{c}}$ & $25.0^{\mathrm{a}, \mathrm{b}, \mathrm{d}}$ & $58.1^{\mathrm{c}}$ & $44.7^{\mathrm{B}}$ & $36.1^{\mathrm{A}}$ & $54.6^{\beta}$ & $37.1^{\alpha}$ \\
\hline
\end{tabular}

${ }^{14}$ For brevity, this table has been shortened to include only the "always or sometimes true" percentages for each category. This can be interpreted for the statement "I try to buy products that can be recycled" as $76.1 \%$ of those who donate regularly to charities claim the statement is always or sometimes true of their behavior, while $23.9 \%$ of those who give to charities claim the statements is never or rarely true of their behavior. ${ }^{15}$ Significant differences are noted by ${ }^{*},{ }^{* *} \cdot{ }^{16}$ Significant differences are noted by a, b, c, d. ${ }^{17}$ Significant differences noted by A, B. ${ }^{18}$ Significant differences noted by $\alpha, \beta$.

Our examination of the lifestyle choices associated with consumer social responsibility adds an important component to the existing literature pertaining to factors that may influence perceptions of CSR. Our finding that those who traveled were more sensitive to most of the social responsibility dimensions, and that mission-related travelers may have even higher social consciousness than other travelers suggests that CSR messaging could be tailored accordingly.

The finding that those involved in volunteer work were more likely to respond "always or sometimes true" to the ethical statements implies that these consumers are also likely to be supportive of CSR initiatives that emphasize ethical dimensions. The majority of respondents who volunteered did so in order to give back to their communities, making it plausible that they would either expect socially responsible corporations to do likewise and/or act to support such organizations via their purchasing.

Results pertaining to charitable giving were particularly interesting. Although more charitable donors than non-donors tried to purchase from corporations who also make charitable donations, the actual percentage of charitable givers selecting "always or sometimes true” in response to seeking companies who donate was not very high (under 60\%). Even more intriguing, while the vast majority (over $80 \%$ ) who gave charitably noted that they did so because their behavior helped those served by the charities; charitable donors who gave because they felt compelled to do so by friends and family had the highest level of agreement with most ethical statements. Here, the implications for CSR expectations are a bit murky, raising the question as to whether such respondents would view CSR behaviors as less compelling if they believed that corporations behaved similarly to them and acted benevolently primarily because of social pressures. This finding may also partially explain why even charitable givers did not overwhelmingly seek out corporations who make donations.

With only a few exceptions, the lowest level of support across demographics and lifestyle choices was seen in the responses to statement 10. This was similar to the findings of Carrigan and Attalla (2001) who reported that working conditions were not a high priority for consumers in their study and explained that their respondents' younger ages may have resulted in less working experience and consequently less sensitivity to workers. Finally, regardless of demographic or lifestyle choices, truth in advertising and responsible depictions of minorities in advertising were highly desirable, eliciting consistently high percentages of consumers indicating that they "always or sometimes" sought these characteristics. It is therefore suggested that corporations ensure that their CSR initiatives cover at least these two criteria which are steadily aligned with the expectations of consumers.

While this analysis was reasonably broad in the personal practices assessed, a limitation of this analysis is the inability to assess respondents' lifestyles more comprehensively. This analysis focused heavily on assessing travel, volunteerism, and charitable giving for respondent-specific lifestyle factors which may be related to social responsibility. Additional factors such as an individual's chosen profession or area of study, outreach activities beyond those investigated, and other interactions with their communities may provide additional insights. Future research may wish to investigate the potential for broadening the lifestyle factors studied.

\section{References}

Auger, P., Devinney, T. M., \& Louviere, J. J. (2007). Using Best-Worst Scaling Methodology to Investigate Consumer Ethi- 
cal Beliefs across Countries. Journal of Business Ethics, 70, 299-326. http://dx.doi.org/10.1007/s10551-006-9112-7

Basil, D. Z., \& Weber, D. (2006). Values Motivation and Concern for Appearances: The Effect of Personality Traits on Responses to Corporate Social Responsibility. International Journal of Nonprofit and Voluntary Sector Marketing, 11, 61-72. http://dx.doi.org/10.1002/nvsm.38

Brunk, K. H. (2010). Exploring Origins of Ethical Company/Brand Perceptions-A Consumer Perspective of Corporate Ethics. Journal of Business Research, 63, 255-262. http://dx.doi.org/10.1016/j.jbusres.2009.03.011

Carrigan, M., \& Attalla, A. (2001). The Myth of the Ethical Consumer-Do Ethics Matter in Purchase Behavior? Journal of Consumer Marketing, 18, 560-577. http://dx.doi.org/10.1108/07363760110410263

Carroll, A. B. (1991). The Pyramid of Corporate Social Responsibility: Toward the Moral Management of Organizational Stakeholders. Business Horizons, 34, 39-48. http://dx.doi.org/10.1016/0007-6813(91)90005-G

Cowe, R., \& Williams, S. (2000). Who Are the Ethical Consumers? Ethical Consumerism Report, Cooperative Bank.

Crane, A., \& Matten D. (2005). Corporate Citizenship: Missing the Point or Missing the Boat? A Reply to van Oosterhout. Academy of Management Review, 30, 681-684. http://dx.doi.org/10.5465/AMR.2005.18378872

Darke, P. R., \& Ritchie, R. J. B. (2007). The Defensive Consumer: Advertising Deception, Defensive Processing, and Distrust. Journal of Marketing Research, 44, 114-127. http://dx.doi.org/10.1509/jmkr.44.1.114

Elkington, J., \& Hailes, J. (1989). The Green Consumer Guide. London: Gollancz.

Fox, H. (2012). Their Highest Vocation: Social Justice and the Millennial Generation. New York: Peter Lang.

Fox, N., \& Ward, K. (2008). Health, Ethics and Environment: A Qualitative Study of Vegetarian Motivations. Appetite, 50, 422-429. http://dx.doi.org/10.1016/j.appet.2007.09.007

Galavielle, J. P. (2004). Business Ethics Is a Matter of Good Conduct and of Good Conscience? Journal of Business Ethics, 53, 9-16. http://dx.doi.org/10.1023/B:BUSI.0000039396.22731.a1

Golob, U., Lah, M., \& Jančič, Z. (2008). Value Orientations and Consumer Expectations of Corporate Social Responsibility. Journal of Marketing Communications, 14, 83-96. http://dx.doi.org/10.1080/13527260701856525

Maignan, I. (2001). Consumers' Perceptions of Corporate Social Responsibilities: A Cross-Cultural Comparison. Journal of Business Ethics, 30, 57-72. http://dx.doi.org/10.1023/A:1006433928640

Maloni, M. J., \& Brown, M. E. (2006). Corporate Social Responsibility in the Supply Chain: An Application in the Food Industry. Journal of Business Ethics, 68, 35-52. http://dx.doi.org/10.1007/s10551-006-9038-0

Matten, D., \& Moon, J. (2005). Pan-European Approach: A Conceptual Framework for Understanding CSR. In A. Habisch, M. Wegner, R. Schmidpeter, \& J. J. Corporate (Eds.), Social Responsibility across Europe (pp. 335-356). Berlin: Springer. http://dx.doi.org/10.1007/3-540-26960-6_26

McKendree, M. G. S., Croney, C. C., \& Widmar, N. J. O. (2014). Effects of Demographic Factors and Information Sources on United States Consumer Perceptions of Animal Welfare. Journal of Animal Science, 92, 3161-3173. http://dx.doi.org/10.2527/jas.2014-6874

Nyaw, M. K., \& Ng, I. (1994). A Comparative Analysis of Ethical Beliefs: A Four Country Study. Journal of Business Ethics, 13, 543-555. http://dx.doi.org/10.1007/BF00881299

Roberts, J. A. (1995). Profiling Levels of Socially Responsible Consumer Behavior: A Cluster Analytic Approach and Its Implications for Marketing. Journal of Marketing Theory and Practice, 3, 97-117. http://dx.doi.org/10.1080/10696679.1995.11501709

Roberts, J. A. (1996). Green Consumers in the 1990s: Profile and Implications for Advertising. Journal of Business Research, 36, 217-231. http://dx.doi.org/10.1016/0148-2963(95)00150-6

Schwartz, J., \& Miller, T. (1991). The Earth’s Best Friends. American Demographics, 13, 26-35.

Schwartz, S. H. (1992). Universals in the Content and Structure of Values: Theoretical Advances and Empirical Tests in 20 Countries. Advances in Experimental Social Psychology, 5, 1-65. http://dx.doi.org/10.1016/S0065-2601(08)60281-6

Shaw, D., Grehan, E., Shiu, E., Hassan, L., \& Thomson, J. (2005). An Exploration of Values in Ethical Consumer Decision Making. Journal of Consumer Behaviour, 4, 185-200. http://dx.doi.org/10.1002/cb.3

Siegrist, M., Visschers, V. H., \& Hartmann, C. (2015). Factors Influencing Changes in Sustainability Perception of Various Food Behaviors: Results of a Longitudinal Study. Food Quality and Preference, 46, 33-39. http://dx.doi.org/10.1016/j.foodqual.2015.07.006

Skarmeas, D., \& Leonidou, C. N. (2013). When Consumers Doubt, Watch Out! The Role of CSR Skepticism. Journal of Business Research, 66, 1831-1838. http://dx.doi.org/10.1016/j.jbusres.2013.02.004

Te Velde, H. T., Aarts, N. \& Van Woerkum, C. (2002). Dealing with Ambivalence: Farmers’ and Consumers’ Perceptions of Animal Welfare in Livestock Breeding. Journal of Agricultural and Environmental Ethics, 15, 203-219.

http://dx.doi.org/10.1023/A:1015012403331 
Vanhonacker, F., Verbeke, W., Van Poucke, E., \& Tuyttens, F. A. M. (2007). Segmentation Based on Consumers’ Perceived Importance and Attitudes toward Farm Animal Welfare. International Journal of Sociology of Food and Agriculture, 15, 84-100.

Verhue, D., \& Verzeijden, D. (2003). Burgeroordelen over de veehouding, uitkomsten publieksonderzoek (Citizens' Judgment about Livestock Production, Results of a Public Research). Research Paper, Amsterdam: Veldkamp.

Wandel, M., \& Bugge, A. (1997). Environmental Concern in Consumer Evaluation of Food Quality. Food Quality and Preference, 8, 19-26. http://dx.doi.org/10.1016/S0950-3293(96)00004-3

Wehrmeyer, W. (1992). Strategic Issues. In M. Charter (Ed.), Greener Marketing (1st Edition): A Responsible Approach to Business (pp. 95-110). Sheffield: Greenleaf Publishing. http://dx.doi.org/10.9774/gleaf.978-1-907643-57-6_5 